\title{
Host selection of the symbiotic copepod Clausidium dissimile in two sympatric populations of ghost shrimp
}

\author{
J. L. Corsetti ${ }^{1}$, K. M. Strasser ${ }^{2, *}$ \\ ${ }^{1}$ Department of Biology, University of Tampa, 401 W Kennedy Blvd., Tampa, Florida 33606, USA \\ ${ }^{2}$ Biological Sciences Department, Ferris State University, 820 Campus Drive, ASC 2004, Big Rapids, Michigan 49307, USA
}

\begin{abstract}
Ghost shrimp, Lepidophthalmus louisianensis (Schmitt 1935) and Sergio trilobata (Biffar 1970) are 2 common burrowing decapod crustaceans in Tampa Bay, Florida, which affect the benthic community through bioturbation. The burrow also plays a crucial role in determining benthic community structure, since it may house several symbionts, one of which is the copepod Clausidium dissimile Wilson, 1921. This study was conducted to investigate factors that affect the density of $C$. dissimile on ghost shrimp specimens both in the field and in the laboratory. Collections of $L$. louisianensis and $S$. trilobata were made over a 15 mo period to determine the prevalence of $C$. dissimile in the field. Analysis of monthly field data showed that host shrimp $(p=0.0001)$, and sampling month $(\mathrm{p}=0.0310)$ were significantly correlated with the host-size adjusted density of the symbiont C. dissimile, with more copepods preferring specimens of S. trilobata over L. louisianensis. Although host sex did not have a significant effect on host-size adjusted copepod density, percentage prevalence of copepods was significantly higher for females than males in S. trilobata ( $\mathrm{p}<0.0001$ ). Laboratory experiments supported observations from the field in that $C$. dissimile significantly preferred $S$. trilobata over L. louisianensis $(\mathrm{p}<0.001)$. However, unlike the field data, copepods did not appear to prefer female over male hosts when size was held constant. Higher colonization of females than males in the field may instead be attributed to differences in size and behavior between the sexes.
\end{abstract}

KEY WORDS: Clausidium dissimile $\cdot$ Ghost shrimp · Host selection · Copepod - Sergio trilobata · Lepidophthalmus louisianensis

\section{INTRODUCTION}

Ghost shrimp are burrowing decapod crustaceans that predominantly inhabit shallow intertidal and occasionally subtidal areas with soft sediment in tropical and temperate regions (Berkenbusch \& Rowden 1999). They are also typically found in regions of high organic content, which triggers settlement in at least 1 species (Strasser \& Felder 1999). They are an important component of the ecosystem, affecting nutrient cycling, sediment turnover rates and benthic community structure, as well as aquaculture through bioturbation (Felder \& Griffis 1994, Nates \& Felder 1998, Berkenbusch \& Rowden 2000). Like many species of ghost shrimp, those in the genus Lepidophthalmus impact penaeid aquaculture by decreasing shrimp production in the ponds (Nates \& Felder 1998). Lepidophthalmus louisianensis (Schmitt, 1935) is also thought to influence the structure and species composition of natural intertidal habitats due to bioturbating activities (Jackson 1996). Sediment suspended during construction and maintenance of their burrows (Lafferty \& Kuris 1996) may impact filter-feeding organisms, such as oysters, by reducing their ability to feed effectively (Stevens 1929). Temperature and salinity affect intertidal decapod populations (Berkenbusch \& Rowden 2000). Low temperatures cause ghost shrimp to be relatively inactive, leading to a decrease in sediment 
turnover rates (Berkenbusch \& Rowden 1999) and in the effect these organisms have on their environment.

The burrows of ghost shrimp may house several species. These symbionts are generally thought to be either parasitic or commensal and include a variety of organisms, such as copepods, pea crabs, Leptalpheid shrimp, clams, gobiid fish and polychaete worms (Jackson 1996). The symbiotic copepod of interest in this study is Clausidium dissimile Wilson, 1921, which lives mainly in the gill chamber and on the body surface of many species of ghost shrimp (Wilson 1935, Gooding 1963). Clausidium spp. have a wide distribution and occur on both coasts of the USA, the Gulf of Mexico, Canada, India, Senegal and Peru. C. dissimile has also been found on Callichirus major in North Carolina (Pohl 1946), Callianassa stimpsoni in Massachusetts (Humes 1949), and Sergio trilobata (Biffar 1970) and Lepidophthalmus louisianensis in Pensacola Bay, Florida (Hayes 1976).

Although it has often been suggested that members of the genus Clausidium spp. are parasitic on their host organisms (Wilson 1935, Pillali 1959), this has yet to be shown quantitatively (Hayes 1976). There is very little information regarding the behavior of these copepods or how they interact with their host and with the environment they inhabit. Marin \& Nascimento (1993) analyzed the body size and habitat of Callichirus garthi as factors affecting the distribution, abundance and fecundity of Clausidium spp. The results of that study suggested that the density of Clausidium spp. per host was dependent upon host habitat type and recruitment. The diet of $C$. dissimile has been studied through gut content analysis, and found to contain diatom frustules from Actinoptychus, Codinodiscus, Thalassiosira and an unidentified genus, as well as an unidentifiable mass (Hayes 1976). It has not been determined whether these copepods consume part of their host, or whether diatoms are consumed without harm to the host (Hayes 1976). Adult copepods attach to the host with 2 sucking disks located on the endopod of leg 1 and commonly skim along the surface of the host without losing contact (Hayes 1976). They are occasionally observed swimming free of the host; however, this behavior is rare and lasts only 1 to $2 \mathrm{~s}$ (Hayes 1976).

Two species of ghost shrimp, Sergio trilobata and Lepidophthalmus louisianensis, have been observed in the Tampa Bay area. L. louisianensis is distributed over the western Atlantic coast and the Gulf of Mexico (Manning \& Felder 1991, Felder \& Rodrigues 1993, Nates et al. 1997). The highest densities of Lepidophthalmus spp. have typically been found in regions of high organic content in the sediments (Nates \& Felder 1998, Nates \& Felder 1999). S. trilobata was described from Tampa Bay but has also been reported in Miami and Lemon Bay, Florida (Biffar 1971, Manning \&
Lemaitre 1993). Sergio spp. also thrive in regions of high organic content and are thought to have a thicker burrow than other species of ghost shrimp in south Florida (Biffar 1971).

The density of symbiotic copepods appears to vary between the similar-sized host species Sergio trilobata and Lepidophthalmus louisianensis. This study investigated factors that may affect the host selection process of Clausidium dissimile. The first objective was to determine the factors that affect the density of $C$. dissimile on individual ghost shrimp hosts. The tested factors were the species of ghost shrimp (L. louisianensis or $S$. trilobata), month of collection, sex of the host organism, size of the host organism, reproductive activity of the host organism and ovary width of the host organism. The second objective of this study was to determine whether (1) specimens of C. dissimile would preferentially choose a host (based on species, sex and size of the host) in laboratory experiments and (2) observed preferences correspond to frequencies observed in natural populations.

\section{MATERIALS AND METHODS}

Preference of Clausidium dissimile in the field. Collections of Lepidophthalmus louisianensis and Sergio trilobata were made on an intertidal sand flat located on the SW end of the Gandy Bridge in Tampa, Florida from June 2000 to November 2001. Specimens were extracted from randomly chosen burrow holes using yabby pumps and $1 \mathrm{~mm}$ mesh sieves (Felder 1978). Monthly samples consisted of ca. 30 animals: 15 of each species. Each shrimp was placed in an individual clean whirl-pack plastic bag $(177 \mathrm{ml})$ to prevent loss or movement of copepods.

In the laboratory, each shrimp was removed from its bag and carefully examined to remove and count female specimens of Clausidium dissimile living with the animal. Copepods were removed from their hosts into a clean petri dish by carefully spraying the ghost shrimp with freshwater. Sex, total length (TL, measured from the tip of the rostrum to the posterior end of the telson) and carapace length (CL, measured from the tip of the rostrum to the posterior end of the carapace) were recorded for each ghost shrimp. The ovary width of females was recorded dorsally on the second abdominal segment at the widest point visible. All measurements were made to the nearest $\mathrm{mm}$. The eggs of ovigerous ghost shrimp were counted, when possible. After all measurements were recorded, individual specimens were preserved in $70 \%$ ethanol.

Analysis of field data. Fisher's Exact Test was used to determine whether the prevalence of Clausidium dissimile (proportion of hosts with at least 1 copepod) 
varied between host species Sergio trilobata and Lepidophthalmus louisianensis, between adults and juveniles, and between the sexes of each host species for all monthly samples combined. The number of copepods per host (copepod density) was divided by the TL of the ghost shrimp to normalize for size of the host (hostsize adjusted copepod density). A Mann-Whitney $U$ test was used to compare the copepod density, and host-size adjusted copepod density of each host species, males versus females, and adults versus juveniles of each host species for all samples combined. A repeated measures ANOVA (Model II sum of squares) was used to determine whether host-size adjusted copepod density varied significantly between host species, sexes and month of collection. A Mann-Whitney $U$-test was used to test whether the presence of eggs had a significant effect on the density of copepods per female host. A simple linear regression was used to determine whether ovary width of females and size of the host organism (males and females) had significant effects on the density of copepods.

Behavioral preference experiments in the laboratory. To determine whether findings from field collections reflected preferences of Clausidium dissimile, a series of 7 experiments (Table 1) were conducted in the laboratory. Collections of Lepidophthalmus louisianensis and Sergio trilobata for use in preference experiments were made from the same location in Tampa,
Florida in July and August 2001. Ghost shrimp were placed in perforated plastic vials with each species in a separate bucket for transportation to the laboratory to assure that the host species of copepods could be ascertained. Prior to use, all ghost shrimp were carefully dipped in deionized water until all specimens of C. dissimile were removed and hosts were then maintained in filtered sea water ( $30 \%$ salinity) with no C. dissimile present. Copepods were placed in filtered seawater in separate containers according to what species of ghost shrimp they had inhabited. Therefore copepods could be identified as originating from $S$. trilobata or L. louisianensis. Sea water used in preference experiments was collected from Fort Desoto State Park, Florida, filtered through steel wool and diluted with deionized water to $30 \%$ salinity.

For each of the 7 experiments, a testing chamber (Fig. 1) was placed in each of 5 aquariums (9.5 l) filled with filtered sea water. The testing chamber was constructed using a small circular plastic container with 4 equidistant holes drilled into the bottom. To house the ghost shrimp, 4 clear vinyl (PVC) tubes $(1.59 \mathrm{~cm}$ in diameter, $15.24 \mathrm{~cm}$ in length) were secured in place with non-toxic silicone. The end of each tube was covered with 3 overlapping layers of screening $(1 \mathrm{~mm} \times$ $1 \mathrm{~mm}$ ) and secured with a rubber band to ensure that all the animals remained in the testing chamber while allowing water exchange.

Table 1. Clausidium dissimile. Summary of host preference experiments. Factors tested were host species (Sergio trilobata or Lepidophthalmus louisianensis), host sex, host size and species of ghost shrimp originally inhabited by the copepods. Trials used 20 copepods (40 for Expt 7) and up to 4 shrimp

\begin{tabular}{|c|c|c|c|c|c|c|}
\hline Expt & $\begin{array}{l}\text { Factor } \\
\text { tested }\end{array}$ & Host species & $\begin{array}{l}\text { Sex of } \\
\text { host }\end{array}$ & $\begin{array}{l}\text { Size of host in mm } \\
\text { (mean TL } \pm \text { SD) }\end{array}$ & $\begin{array}{l}\text { Source of } \\
\text { copepods }\end{array}$ & $\begin{array}{l}\text { No. of } \\
\text { trials }\end{array}$ \\
\hline 1 & Host species & $\begin{array}{l}\text { L. louisianensis } \\
\text { and S. trilobata }\end{array}$ & Female & $\begin{array}{l}\text { Hosts within } 5 \mathrm{~mm} \mathrm{TL} \\
\text { of each other }\end{array}$ & S. trilobata & 10 \\
\hline 2 & Host species & $\begin{array}{l}\text { L. louisianensis } \\
\text { and S. trilobata }\end{array}$ & Female & $\begin{array}{l}\text { Hosts within } 5 \mathrm{~mm} \mathrm{TL} \\
\text { of each other }\end{array}$ & L. louisianensis & 5 \\
\hline 3 & Host size & S. trilobata & Male & $\begin{array}{l}\text { Small } 44.8 \pm 0.5 \\
\text { Large } 67.8 \pm 3.1\end{array}$ & S. trilobata & 5 \\
\hline 4 & Host size & S. trilobata & Female & $\begin{array}{l}\text { Small } 51.6 \pm 2.9 \\
\text { Large } 75.8 \pm 4.1\end{array}$ & S. trilobata & 5 \\
\hline 5 & Host sex & S. trilobata & $\begin{array}{l}\text { Male/ } \\
\text { female }\end{array}$ & $\begin{array}{l}\text { Small } \\
\text { Males } 48.6 \pm 4.5 \\
\text { Females } 48.6 \pm 5.4\end{array}$ & S. trilobata & 5 \\
\hline 6 & Host sex & S. trilobata & $\begin{array}{l}\text { Male/ } \\
\text { female }\end{array}$ & $\begin{array}{l}\text { Large } \\
\text { Males } 67.8 \pm 4.6 \\
\text { Females } 70.0 \pm 1.7\end{array}$ & S. trilobata & 5 \\
\hline 7 & $\begin{array}{l}\text { Host sex } \\
\text { and size }\end{array}$ & S. trilobata & $\begin{array}{l}\text { Male/ } \\
\text { female }\end{array}$ & $\begin{array}{l}\text { Small } \\
\text { Males } 50.0 \pm 2.0 \\
\text { Females } 51.0 \pm 2.9 \\
\text { Large } \\
\text { Males } 70.6 \pm 1.7 \\
\text { Females } 72.4 \pm 2.7\end{array}$ & S. trilobata & 5 \\
\hline
\end{tabular}




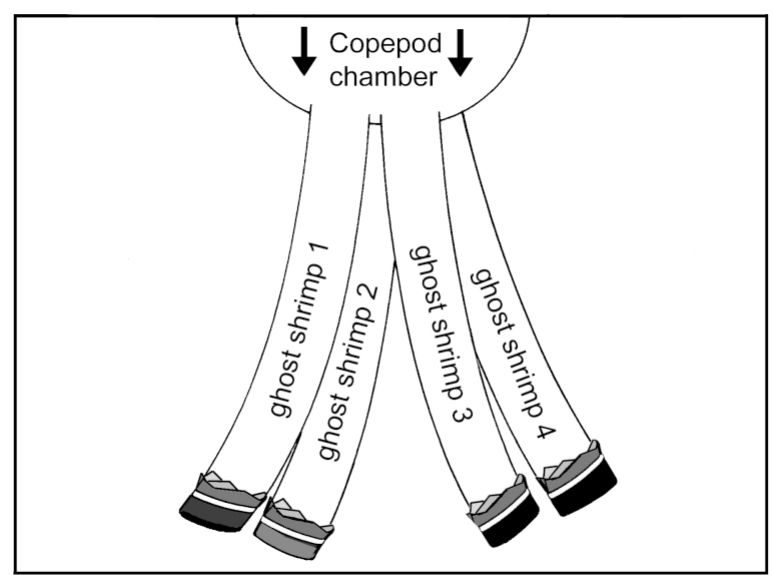

Fig. 1. Experimental chamber used in laboratory preference experiments. Arrows indicate where copepods were introduced into the chamber at the beginning of the experiment. Ghost shrimp were located near the bottom of the tubes throughout each experiment

During each experimental trial (see Table 1), ghost shrimp were randomly assigned to the tubes (1 shrimp in each), generally maintaining a position near the bottom of the tubes. Two tubes were filled with cotton for trials in which only 2 host specimens were used, and 20 specimens of Clausidium dissimile were then placed in the center of the copepod chamber using a pipette. The copepods could then swim horizontally for a short distance in order to reach the tubes in which the host organisms were located. Although ghost shrimp were not physically prevented from entering the copepod chamber and subsequently switching tubes, this activity was not observed. Similarly, ghost shrimp in the field are thought not to leave their burrows through the top opening. Copepods were taken originally from either Sergio trilobata or Lepidophthalmus louisianensis, depending on the experiment (Table 1). In Expt 7 , however, 40 specimens of Clausidium dissimile were placed in the testing chamber because there were 4 shrimp used in each trial. In all experiments in which size was not the tested factor, the ghost shrimp used were within $5 \mathrm{~mm}$ TL of each other. In experiments in which size was the tested factor, ghost shrimp had a minimum size difference of $20 \mathrm{~mm}$ TL.

The number of copepods located on each ghost shrimp (or not attached to a host) was determined after an $8 \mathrm{~h}$ period. At this time, ghost shrimp were removed from the tubes by taking the testing chamber out of the aquarium, removing the screening and placing the shrimp from each tube in separate glass bowls. All organisms used in trials were preserved in $70 \%$ ethanol.

In Expts 1 to 6 the proportion of copepods selecting a particular host was analyzed using a replicated goodness-of-fit test, the $G$-test (Sokal \& Rohlf 1981). This proportional data is presented as percentages in the text and figures. Expts 1 and 2 were conducted to determine whether Clausidium dissimile would exhibit a preference for either Sergio trilobata or Lepidophthal-

Table 2. Clausidium dissimile. Data from field collections. $\mathrm{n}$ = individuals from all sample months combined. Percent prevalence compared between total specimens of each host species, males versus females Sergio trilobata and adults versus juveniles of $S$. trilobata with Fisher's Exact test. Copepod density (mean $\pm \mathrm{SE}$ ) and host-size adjusted copepod density (copepod density/TL of host, mean $\pm \mathrm{SE}$ ) compared between total specimens of each host species, males versus females $S$. trilobata, and adults versus juveniles of $S$. trilobata with the Mann-Whitney $U$-test

\begin{tabular}{|c|c|c|c|c|}
\hline Host species & $\mathrm{n}$ & $\begin{array}{c}\text { Prevalence (\% of } \\
\text { hosts with } \geq 1 \text { copepod) }\end{array}$ & $\begin{array}{l}\text { Copepod density (ind. } \\
\text { per host; mean } \pm \mathrm{SE} \text { ) }\end{array}$ & $\begin{array}{c}\text { Host-size adjusted } \\
\text { copepod density (mean } \pm \mathrm{SE})\end{array}$ \\
\hline \multicolumn{5}{|c|}{ Lepidophthalmus louisianensis } \\
\hline Adult & 233 & 67 & $5.4 \pm 0.7$ & $0.088 \pm 0.011$ \\
\hline Male & 65 & 65 & $4.2 \pm 0.9$ & $0.069 \pm 0.015$ \\
\hline Female & 168 & 68 & $5.9 \pm 0.1$ & $0.095 \pm 0.015$ \\
\hline Juvenile & 10 & 50 & $2.1 \pm 1.0$ & $0.079 \pm 0.042$ \\
\hline Total & 243 & 66 & $5.3 \pm 0.7$ & $0.087 \pm 0.011$ \\
\hline \multicolumn{5}{|c|}{ Sergio trilobata } \\
\hline Adult & 298 & 97 & $13.3 \pm 0.8$ & $0.203 \pm 0.011$ \\
\hline Male & 93 & 92 & $10.0 \pm 1.0$ & $0.180 \pm 0.017$ \\
\hline Female & 205 & $99^{a}$ & $14.8 \pm 1.1^{\mathrm{a}}$ & $0.210 \pm 0.014$ \\
\hline Juvenile & 21 & $71^{b}$ & $2.4 \pm 0.5^{\mathrm{b}}$ & $0.075 \pm 0.017^{b}$ \\
\hline Total & 319 & $95^{\mathrm{c}}$ & $12.6 \pm 0.8^{\mathrm{c}}$ & $0.194 \pm 0.001^{\mathrm{c}}$ \\
\hline \multicolumn{5}{|c|}{$\begin{array}{l}\text { a Significantly higher for female } S \text {. trilobata than for males. Prevalence: } \mathrm{p}=0.012 \text {; copepod density: } \mathrm{p}=0.0084 \\
{ }^{\mathrm{b}} \text { Significantly higher for adult } S \text {. trilobata than for juveniles. Prevalence and host-size adjusted copepod density: } \mathrm{p}=0.0002 \text {; } \\
\text { copepod density: } \mathrm{p}<0.0001 \\
\text { cSignificantly higher than for } L \text {. louisianensis, } \mathrm{p}<0.0001\end{array}$} \\
\hline
\end{tabular}


mus louisianensis, and differed only in terms of the source host. Expts 3 to 7 were conducted to examine how size and sex of the host affected selection behavior. Expts 3 and 4 tested the preference of $C$. dissimile for large or small male (Expt 3) and female (Expt 4) hosts. Expts 5 and 6 were conducted to determine if copepods would exhibit a preference for either sex when size of the host was held constant, using either small (Expt 5) or large (Expt 6) host specimens. Expt 7 tested the preference of $C$. dissimile for the sex and size of the host, when both factors were combined; the data were analyzed using Fisher's Exact Test.

\section{RESULTS}

\section{Monthly field collections}

Clausidium dissimile colonizes Sergio trilobata at a higher frequency than Lepidophthalmus louisianensis. When data from all months were combined, the mean percentage prevalence (percentage of shrimp with at least one copepod attached), copepod density (number of copepods per host), and host-size adjusted copepod density (number of copepods/TL of host) were all significantly higher for $S$. trilobata, than for L. louisianen-
Table 3. Results of repeated measures ANOVA (Model II sum of squares) showing the effects of host species, host sex, sampling month, and interaction effects on the host-size adjusted copepod density (no. of copepods per host/TL of host). Significant independent variables are shown in bold

\begin{tabular}{|lrcccc|}
\hline Source & df & SS & MS & $F$ & $p$ \\
\hline Host species & 1 & 0.994 & 0.994 & 53.1 & 0.0001 \\
Host sex & 1 & 0.005 & 0.005 & 0.253 & 0.6258 \\
Host species $\times$ Host sex & 1 & 0.003 & 0.003 & 0.140 & 0.7464 \\
Subject (group) & 10 & 0.187 & 0.019 & & \\
Months & 16 & 1.001 & 0.063 & 1.833 & 0.0310 \\
Months $\times$ Host species & 16 & 0.642 & 0.40 & 1.175 & 0.2930 \\
Months $\times$ Host sex & 16 & 0.325 & 0.020 & 0.596 & 0.8840 \\
Months $\times$ Host species $\times$ Host sex & 16 & 0.712 & 0.045 & 1.304 & 0.2002 \\
Months $\times$ Subject (Group) & 160 & 5.461 & 0.034 & & \\
\hline
\end{tabular}

sis (Table 2). For S. trilobata, the percentage prevalence and copepod density were significantly higher for adults than for juveniles, and for females over males. When host size was eliminated as a factor by examining host-size adjusted copepod density, adults differed significantly from juveniles, but males and females did not differ significantly for $S$. trilobata. There were no significant differences in percentage prevalence, copepod density, or host-size adjusted copepod density between adults and juveniles and between males and females of $L$. louisianensis.

Host species and sampling month had significant effects on host-size adjusted copepod density (Table 3). Although female specimens of each host species generally had a higher host-size adjusted copepod density than males, host sex was not a significant factor. None of the interaction effects were significant. Juveniles were not present all year and thus only adult specimens were included in this analysis. For all but 2 collections (September 2000 and September 2001, Fig. 2), specimens of Sergio trilobata had a higher mean host-size adjusted copepod density than specimens of Lepidophthalmus louisianensis. Host-size adjusted density of Clausidium dissimile also varied seasonally (Fig. 2). Overall, host-size adjusted densities of $C$. dissimile were higher in the fall than they were in the spring and summer on both species of ghost shrimp with the exception of $S$. trilobata in the fall of 2001 where a decline in host-size adjusted copepod density was observed (Fig. 2).

Copepod density on Sergio trilobata was correlated with TL $(F=75.241$; df = $1,423 ; \mathrm{p}<0.0001)$ and $\mathrm{CL}(F=58.299 ; \mathrm{df}=$ $1,423 ; \mathrm{p}<0.0001)$ of the host shrimp.
Fig. 2. Clausidium dissimile. Mean host-size adjusted copepod density $( \pm \mathrm{SE})$ (no. of copepods per host/TL of host) found on specimens of Sergio trilobata and Lepidophthalmus louisianensis during each month of collection from June 2000 to November 2001 (excluding July 2000) 


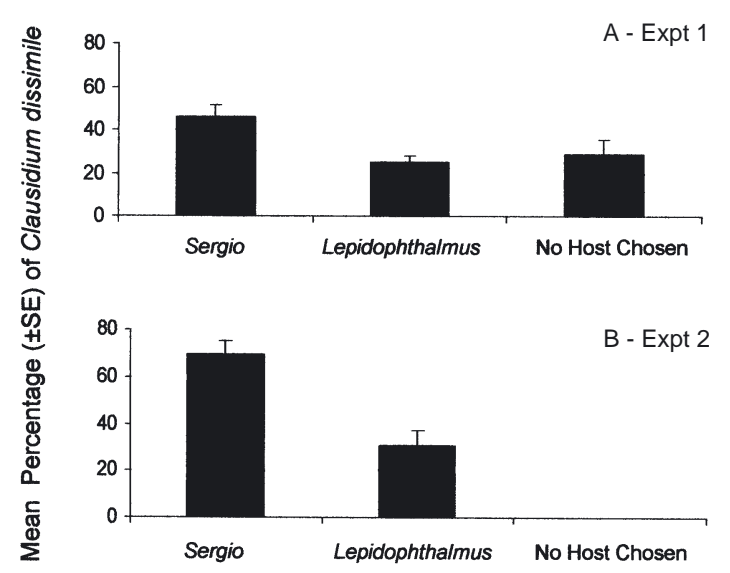

Fig. 3. Clausidium dissimile. Mean percentage $( \pm \mathrm{SE})$ of copepods that chose Sergio trilobata and Lepidophthalmus louisianensis and those that did not choose a host using (A) copepods initially taken from S. trilobata or (B) copepods initially taken from $L$. louisianensis

However, the copepod density on Lepidophthalmus louisianensis was not dependent on TL $(F=3.312$; df $=$ $1,423 ; \mathrm{p}=0.07)$ or $\mathrm{CL}(F=1.142 ; \mathrm{df}=1,423 ; \mathrm{p}=0.2826)$ of the host shrimp. The field data also showed that reproductive activity of females, measured as the presence of eggs, did not have a significant effect on the density of Clausidium dissimile ( $S$. trilobata: $\mathrm{p}=$ 0.7457; L. louisianensis: $\mathrm{p}=0.3334$ ). Ovary size had a significant effect on copepod density on $L$. louisianensis $\left(F=5.999 ; \mathrm{df}=1,156 ; \mathrm{p}=0.0154 ; \mathrm{r}^{2}=0.037\right)$, as greater ovary widths correlated with lower copepod densities. However, for $S$. trilobata, ovary width did not have a significant effect $(F=2.44 ; \mathrm{df}=1,172 ; \mathrm{p}=0.12$; $\left.r^{2}=0.014\right)$

\section{Laboratory preference experiments}

Results of Expt 1 using copepods collected from Sergio trilobata, mirrored the field data in that Clausidium dissimile exhibited a significant preference for $S$. trilobata over Lepidophthalmus louisianensis $(G=19.176$; $\mathrm{df}=7 ; \mathrm{p}<0.001$ ) (Fig. 3A). The mean percentages $( \pm \mathrm{SE})$ of $C$. dissimile that chose $S$. trilobata and $L$. louisianensis were $46.0 \pm 5.7$, and $25.0 \pm 2.8$, respectively. Expt 2 (using copepods taken from L. louisianensis) also revealed a preference of $C$. dissimile for $S$. trilobata over L. louisianensis $(G=22.041$; $\mathrm{df}=7$; $\mathrm{p}<$ 0.0005). The mean percentages of $C$. dissimile that chose $S$. trilobata and L. louisianensis were $69.1 \pm 6.2$ and $30.9 \pm 6.22$, respectively (Fig. 3B).

In Expt 3, C. dissimile showed a significant preference for small males of $S$. trilobata over large males $(G=$ $20.502 ; \mathrm{df}=7 ; \mathrm{p}<0.0005)$. The mean percentage $( \pm \mathrm{SE})$ of copepods that chose small male shrimp $(58.0 \pm 3.4)$ was significantly higher than the mean percentage that chose large male shrimp (21.0 \pm 3.7$)$ (Fig. 4A). This data differs from the results of Expt 4 (Fig. 4B) in which the mean percentage of $C$. dissimile that chose small females $(25.0 \pm 2.2)$ was significantly lower $(G=16.718$; $\mathrm{df}=7 ; \mathrm{p}<0.05)$ than the mean percentage that chose large females $(61.0 \pm 6.4)$ (Fig. 4B). To isolate host sex as a potential factor, experiments were conducted with only small (Expt 5) or large (Expt 6) potential hosts; however, no significant preference for males or females was determined (Fig. 4 C, D). Expt 5 demonstrated that
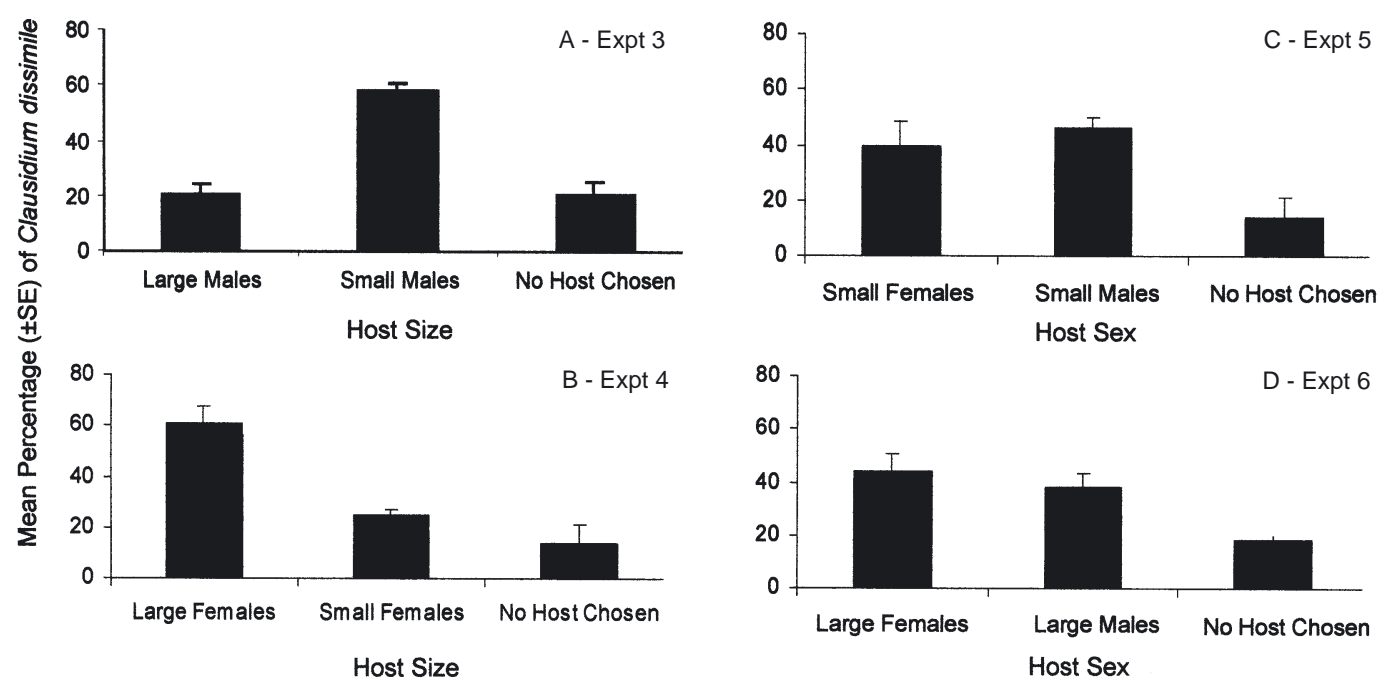

Fig. 4. Clausidium dissimile. Mean percentage $( \pm \mathrm{SE})$ of copepods that chose each sex or size of host Sergio trilobata and those that did not choose a host (A) large and small male hosts, (B) large and small female hosts, (C) small male and female hosts, (D) large male and female hosts 


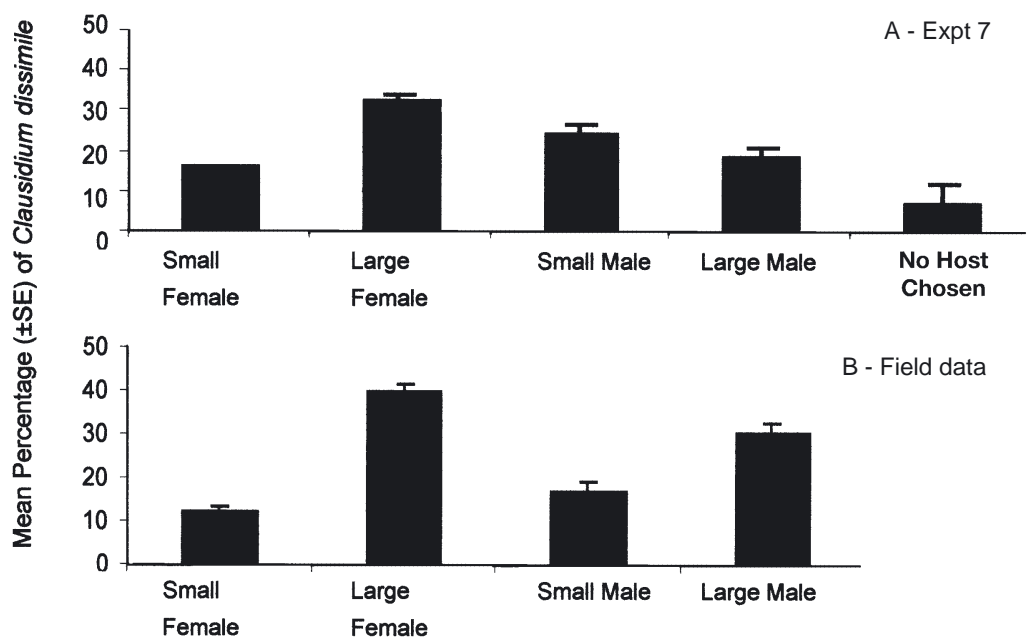

Fig. 5. Clausidium dissimile. Mean percentage $( \pm \mathrm{SE})$ of copepods that chose each sex and size of host Sergio trilobata. (A) data taken from Expt 7. (B) data taken from specimens collected in the field that matched size-ranges used in Expt 7

C. dissimile had no preference for small males or females $(G=5.747$; df $=7$; p < 0.50) (Fig. 4C). The mean percentage of copepods that chose small males $(46.0 \pm$ 4.0) was slightly larger than the mean percentage that chose small females $(40.0 \pm 6.4)$ (Fig. 4C). Similarly, Expt 6 indicated that $C$. dissimile had no preference for large males or females $(G=7.969$; df $=7$; p < 0.40). The mean percentage of $C$. dissimile that chose large males $(38.0 \pm 5.4)$ was slightly lower than the mean percentage that chose large females $(44.0 \pm 6.8)$ (Fig. 4D). When sex and size of $S$. trilobata were tested simultaneously in Expt 7, the higher percentages of C. dissimile were found on large females $(33.0 \pm 2.3)$ and small males $(24.5 \pm 2.7)$, whereas small females $(16.5 \pm 1.5)$ and large males $(18.5 \pm 5.0)$ had fewer $C$. dissimile $(G=$ 15.045; df $=1 ; \mathrm{p}=0.0001$ ) (Fig. 5A). A comparison with shrimp of a similar size collected in the field demonstrated an inconsistency with the experimental data. In the field, $C$. dissimile was found more frequently on large females $(39.8 \pm 1.7 \%)$ and large males $(30.5 \pm$ $2.4 \%)$, than on small females $(12.6 \pm 0.8 \%)$ and small males $(17.1 \pm 2.5 \%$ ) (Fig. $5 \mathrm{~B})$.

\section{DISCUSSION}

The host-size adjusted density of Clausidium dissimile was affected by the host species and the month sampled. The results of both monthly field collections and preference experiments showed that $C$. dissimile significantly preferred Sergio trilobata over Lepidophthalmus louisianensis, no matter which host C. dissimile had formerly inhabited. It could be that either $C$. dissimile is attracted to $S$. trilobata or $L$. louisianensis repels the symbiont, possibly through removal by grooming behavior. Another possibility is that the feeding mechanism of $S$. trilobata and L. louisianensis may influence the abundance of copepods. Ghost shrimp feed in a variety of ways including filtration of plankton and deposit feeding, and generally consume microalgae and other diatoms (Felder \& Griffis 1994). Most callianassid ghost shrimp feed by sifting sand for microscopic organisms using their mouth parts to remove food particles from setae of the maxillipeds (Pohl 1946). Gut content analysis of L. louisianensis has shown that the main dietary constituents are diatoms and other microalgae commonly found in the sediment (Felder \& Griffis 1994) while both the feeding mechanisms and dietary intake of $S$. trilobata are unknown. Nevertheless, recruitment of the planktonic host-seeking stage of copepods-Copepodid I in C. dissimile (Hayes 1976) - may depend on the host's feeding mechanism.

The apparent preference for host sex was not consistent between the field and experimental evidence for Sergio trilobata. In field collections the proportion of hosts with Clausidium dissimile (percentage prevalence) was significantly higher for females than males, except when corrected for host size (Table 2). No such relationship was observed in preference experiments with $S$. trilobata. There was no significant difference in the number of copepods selecting either sex when the size of each potential host was similar. This could signify that copepods base their selection of host primarily on the size of the organism. Since females are generally larger in size $(68.2 \pm 2.2 \mathrm{~mm}$, mean $\pm \mathrm{SE})$ in the field than males $(54.6 \pm 5.4 \mathrm{~mm})$, higher copepod infestation on female specimens may be a result of size and not sex. The lack of a significant difference between the sexes in copepod density supports this hypothesis.

TL in Sergio trilobata, but not in Lepidophthalmus louisianensis, was correlated with the mean number of Clausidium dissimile present. This could be a sampling artifact because there were simply too few copepods found on L. louisianensis to determine a preference for the host size or sex. In $S$. trilobata, the total length of the organism was indicative of the number of symbionts present, which suggests that there is a host carrying capacity. Smaller individuals may be able to support fewer copepods than larger host specimens. Copepods may redistribute themselves to reduce competition for food resources, assuming they feed on sus- 
pended plankton and other particles pumped into the burrow by the shrimp (Hayes 1976). The correlation between abundance of copepods and the size of $S$. trilobata confirms the results of another study in which the abundance of Clausidium sp. was directly related to the size of Callichirus garthi (= Callianassa garthi, Marin \& Nascimento 1993). The authors suggested that the larger the animal the more time the copepods have had to associate with the host (Marin \& Nascimento 1993). This explanation suggests that copepods remain with the host initially colonized. In our study, copepods moved between host shrimp kept in the same collecting bucket. This was especially apparent when host specimens were injured; copepods generally abandoned injured or dying ghost shrimp specimens.

Chemoreception serves for host recognition in many groups of symbiotic crustaceans (Jackson 1996). The size of Sergio trilobata could be related to its chemical cue; a larger animal may emit a stronger signal than a smaller animal. During laboratory experiments, Clausidium dissimile displayed a significant preference for small males and large females of S. trilobata. However, in field data, large males and females were preferred over smaller specimens. If the strength of the signal was a critical factor in promoting a preference for a host, perhaps activity level contributes to disseminating this chemical signal. While only healthy shrimp were used, larger specimens exhibited higher mortality rates than smaller specimens. Although no attempt was made to quantify activity level, larger specimens appeared to be less active than smaller specimens. Therefore, the higher activity of small males may have attracted more copepods to them. However, this does not explain why copepods selected larger females in the laboratory.

If a size-related chemical signal is used to explain copepod preference, it does not account for the significantly higher prevalence of copepods on females than males of Sergio trilobata. However, the differences in behavior between the sexes could be a factor. In our experience, females are generally collected from the field more often than males. Although natural populations of $S$. trilobata could be female biased, this deviation in the sex ratio could also be due to the behavior of the ghost shrimp. Females more continuously inhabit the upper reaches of the burrow (Nates \& Felder 1999) and could therefore be collected more frequently than males, which may remain deeper in the burrow. The proximity of the shrimp in the burrow may have an effect on the strength of the chemical signal and therefore females living higher in the burrow may attract more copepods. In laboratory experiments, all shrimp were located near the surface of the burrow since the artificial burrow constructed was only approximately $15 \mathrm{~cm}$ in length.

The density of copepods on female ghost shrimp did not differ significantly between ovigerous and non-ovigerous females for either Sergio trilobata or Lepidophthalmus louisianensis. Females with larger ovaries did not have higher copepod densities. In addition, peak periods of reproductive activity for $S$. trilobata do not coincide with seasonal trends in copepod abundance (Corsetti \& Strasser in press) suggesting that the presence of eggs and or developed ovaries has no benefit to the copepods, such as a possible food source. Although copepods inhabit the abdomen and cephalothorax, the greatest density was typically observed in the gill chamber of host specimens.

In the case of a parasitic relationship, potential costs to the host organisms could be decreased mobility, respiration efficiency and feeding efficiency, which could all impact potential reproductive success. However, infested hosts did not appear to be less viable than those without a high copepod load. Even at the maximum infestation rates observed, ca. 90 to 100 copepods per host, the infested shrimp did not exhibit adverse effects. Additionally, reproductive potential of females, assessed as egg number or ovary size, was not negatively affected by increased densities of copepods in this study. Thus we have no evidence that the relationship between Clausidium dissimile and Sergio trilobata or Lepidophthalmus louisianensis is parasitic.

Although it is unclear why copepods would preferentially colonize Sergio trilobata over Lepidophthalmus louisianensis, the consistency between data from field collections and laboratory experiments suggests that such a preference exists. Host sex seems to be unimportant, while host species and size have an impact. Both the mechanism of this selection and the precise nature of the copepod-host relationship warrants further study.

Acknowledgements. We would like to thank all those that assisted in collection of organisms: Mark Driscoll, Amanda Kahn, Kelly Graham and students in the University of Tampa's Ecology class in 2000 and 2001. Funding for this study was provided to J. Corsetti by the University of Tampa Biology Research Fellowship and the University of Tampa Honors Research Fellowship, and to KM Strasser by a University of Tampa Delo grant and Dana grant. We would also like to thank W. Wayne Price, Kevin Beach, and 3 anonymous reviewers for their helpful comments on this manuscript.

\section{LITERATURE CITED}

Berkenbusch K, Rowden AA (1999) Factors influencing sediment turnover by the burrowing ghost shrimp Callianassa filholi (Decapoda: Thalassinidea). J Exp Mar Biol Ecol 238: 283-292

Berkenbusch K, Rowden AA (2000) Latitudinal variation in the reproductive biology of the burrowing ghost shrimp Callianassa filholi (Decapoda: Thalassinidea). Mar Biol 136:497-504 
Biffar TA (1971) The genus Callianassa (Crustacea, Decapoda, Thalassinidea) in South Florida, with keys to the western atlantic species. Bull Mar Sci 21:637-715

Corsetti JL, Strasser KM (in press) Population biology of the ghost shrimp Sergio trilobata (Biffar 1970) (Crustacea: Decapoda: Thalassinidea). Gulf Caribb Res

Felder DL (1978) Osmotic and ionic regulation in several western Atlantic Callianassidae (Crustacea, Decapoda, Thalassinidea). Biol Bull 154:409-429

Felder DL, Griffis RB (1994) Dominant infaunal communities at risk in shoreline habitats: burrowing thalassinid Crustacea. OCS Study MMS 94-0007. U.S. Dept. of the Interior, Minerals Mgmt. Service, Gulf of Mexico OCS Regional Office, New Orleans

Felder DL, Rodrigues SA (1993) Reexamination of the ghost shrimp Lepidophthalmus louisianensis (Schmitt, 1935) from the northern Gulf of Mexico and comparison to L. siriboia, nov. sp. from Brazil (Decapoda: Thalassinidea: Callianassidae). J Crustac Biol 13:357-376

Gooding RU (1963) External morphology and classification of marine poecilostome copepods belonging to the families Clausidiidae, Clausiidae, Nereicolodae, Eunicicolodae, Synapthiphilidae, Catiniidae, Anomopsyllidae, and Echiurophilidae. $\mathrm{PhD}$ thesis, University of Washington

Hayes HJ (1976) Biology of Clausidium dissimile an epizoic copepod. MS thesis, University of West Florida, Pensacola

Humes AG (1949) A new copepod (Cyclopoida: Clausidiidae) parasitic on mud shrimps in Louisiana. Trans Am Microsc Soc 68:93-103

Jackson LJ (1996) Behavioral observations on the symbiotic relationship between the Callianassid, Lepidophthalmus louisianensis (Decapoda: Thalassinidea), and its associate Leptalpheus forceps (Decapoda: Alpheidae). MS thesis. University of Southern Mississippi, Ocean Springs

Lafferty KD, Kuris AM (1996) Biological control of marine pests. Ecology 77:1989-2000

Manning RB, Felder DL (1991) Revision of the American

Editorial responsibility: Gareth Harding (Contributing Editor), Dartmouth, Nova Scotia, Canada
Callianassidae (Crustacea: Decapoda: Thalassinidea). Proc Biol Soc Wash 104:764-792

Manning RB, Lemaitre R (1993) Sergio, a new genus of ghost shrimp from the Americas (Crustacea: Decapoda: Callianiassidae). Nauplius, Rio Grande 1:39-43

Marin SL, Nascimento MG (1993) Host body size and habitat as factors affecting the distribution and abundance of the copepod Clausidium sp. (Cyclopoida), ectosymbiont of the ghost shrimp Callianassa garthi Retanal, 1975 (Crustacea: Thalassinidea). Rev Chil Hist Nat 66:427-437

Nates SF, Felder DL (1998) Impacts of burrowing ghost shrimp, genus Lepidophthalmus Crustacea: Decapoda:Thalassinidea, on penaeid shrimp culture. J World Aquacult Soc 29:188-210

Nates SF, Felder DL (1999) Growth and maturation of the ghost shrimp Lepidophthalmus sinuensis Lemaitre and Rodrigues, 1991 (Crustacea, Decapoda, Callianassidae), a burrowing pest in penaeid shrimp culture ponds. Fish Bull 97:526-541

Nates SF, Felder DL, Lemaitre R (1997) Comparative larval development in the two species of the burrowing ghost shrimp genus Lepidophthalmus (Decapoda: Callianassidae). J Crustac Biol 17:497-519

Pillai KN (1959) On two new species of Clausidium (Copepoda: Cyclopoida) parasitic on the shrimp Callianassa. J Mar Biol Assoc India 1:57-65

Pohl ME (1946) Ecological observations on Callianassa major Say at Beaufort, North Carolina. Ecology 27:71-80

Sokal RR, Rohlf FJ (1981) Biometry. WH Freeman, New York

Stevens BA (1929) Ecological observations on Callianassidae of Puget Sound. Ecology 10:399-405

Strasser KM, Felder DL (1999) Sand as a stimulus for settlement in the ghost shrimp Callichirus major (Say) and C. islagrande (Schmitt) (Crustacea: Decapoda: Thallassinidea). J Exp Mar Biol Ecol 239:211-222

Wilson CB (1935) Parasitic copepods from the Pacific Coast. Am Midl Nat 16:776-797

Submitted: December 19, 2001; Accepted: February 18, 2003 Proofs received from author(s): May 28, 2003 